\title{
PENGARUH CENDAWAN Aspergillus sp. DAN Fusarium sp. TERHADAP VIABILITAS BENIH DAN PERTUMBUHAN BIBIT Swietenia macrophylla
}

\author{
The Effect of Aspergillus sp. and Fusarium sp. Fungi on Seed Viability and Seedling Growth \\ of Swietenia macrophylla
}

\author{
Yulianti Bramasto, Kurniawati P. Putri dan/and Tati Suharti \\ Balai Penelitian Teknologi Perbenihan Bogor \\ Jl. Pakuan Ciheuleut PO. Box 105, Bogor - 16001 \\ Telp./Fax. (0251) 8327768
}

Naskah masuk : 14 Januari 2009; Naskah diterima : 9 Juni 2009

\begin{abstract}
The aim of this research was to investigate the influence of Fusarium sp. and Aspergillus sp. fungi infection at seed viability, height growth and diameter growth of one month old S. macrophylla seedlings. The design of the research was complete random design with 3 treatments: control, Aspergillus sp. and Fusarium sp. inoculation. Each treatment was repeated by 3 times. Parameters observed were seed germination, height growth and diameter growth of seedling. The results showed that Fusarium sp. and Aspergillus sp. infection decreased seed viability that are 36.75\% for Fusarium $s p$. and $15.75 \%$ for Aspergillus sp. The height and diameter of seedling were effected by fungi infection, significantly.
\end{abstract}

Key words: Aspergillus sp., fungi, Fusarium sp., seedling, S. macrophylla

\begin{abstract}
ABSTRAK
Tujuan dari penelitian ini adalah untuk mengetahui pengaruh infeksi cendawan Fusarium sp. dan Aspergillus sp. terhadap viabilitas benih, pertumbuhan tinggi dan diameter bibit $S$. macrophylla umur 1 bulan. Rancangan yang digunakan adalah Rancangan Acak Lengkap (RAL) dengan perlakuan: kontrol, inokulasi Aspergillus sp. dan inokulasi Fusarium sp. Setiap perlakuan diulang 3 kali. Parameter yang diukur meliputi daya kecambah, pertumbuhan tinggi dan diameter bibit umur 1 bulan. Hasil penelitian menunjukkan bahwa inokulasi Fusarium sp. dan Aspergillus sp. menurunkan viabilitas benih $S$. macrophylla hingga mencapai 36,75\% untuk Fusarium sp. dan 15,75\% untuk Aspergillus sp. Inokulasi cendawan Fusarium sp. dan Aspergillus sp. berpengaruh nyata terhadap pertumbuhan tinggi dan diameter bibit S. macrophylla umur 1 bulan.
\end{abstract}

Kata kunci: Aspergillus sp., bibit, cendawan, Fusarium sp., S. macrophylla

\section{PENDAHULUAN}

Mikroorganisme, khususnya cendawan menyerang atau menginfeksi benih karena keberadaan nutrisi tinggi seperti karbohidrat, protein dan lemak yang terkandung dalam benih, yang merupakan sumber makanan bagi mikroorganisme tersebut. Infeksi cendawan dapat menimbulkan kerusakan pada benih, sehingga cendawan menjadi salah satu penyebab menurunnya kesehatan benih (Bramasto et al., 2008).

Cendawan dapat menimbulkan penyakit atau kerusakan pada tanaman dengan cara mengganggu metabolisme sel inang dengan toksin, enzim atau zat pengatur tumbuh yang dihasilkannya (Vijayan dan Rehill, 1990 dalam Schmidt, 2000). Dampak yang ditimbulkan oleh cendawan tersebut dapat terlihat langsung pada tanaman yang berasal dari benih yang terinfeksi dalam tahap perkecambahan, atau akan terlihat setelah tanaman tumbuh dewasa karena cendawan tersebut mampu bertahan dalam habitatnya di 
tanah, sisa tanaman atau pada gulma. Hal ini tentunya akan mempengaruhi pertumbuhan tanaman atau bahkan dapat mempengaruhi produktivitas tegakannya.

Cendawan perusak benih dapat dikelompokkan menjadi dua, yaitu cendawan yang berasal dan terbawa dari lapangan (field fungi) dan cendawan yang berkembang di penyimpanan (storage fungi) (Neegaard, 1979). Fusarium sp. adalah salah satu cendawan dari kelompok cendawan lapang (field fungi) yang dapat menyerang pada semua tahap perkembangan tanaman bahkan mulai dari tahap pembentukan benih (Booth dan Waterson, 1964 dalam Baharuddin et al., 2000). Cendawan ini juga dapat terbawa hingga ke pembibitan dan menyebabkan timbulnya penyakit di pembibitan seperti penyakit rebah (damping off) (Rahayu, 1999). Cendawan gudang banyak terdapat di udara atau mengendap pada permukaan benda-benda yang terdapat dalam ruang penyimpanan benih. Aktivitasnya sangat dipengaruhi kondisi fisik, vitalitas dan kadar air benih, serta suhu dan kelembaban tempat penyimpanan. Aspergillus sp. adalah salah satu jenis cendawan gudang yang banyak menginfeksi benih pada saat penyimpanan (Justice dan Bass, 2002).

Beberapa jenis cendawan cukup berpotensi untuk merusak benih walaupun tingkat infeksinya sangat kecil (Rahayu, 1999). Pengaruh infeksi cendawan tentunya akan berbeda pada setiap jenis dan umur atau tahapan perkembangan tanaman mulai dari bibit sampai tanaman dewasa. Hal ini karena tingkat ketahanan secara individual terhadap cendawan dipengaruhi oleh genotip, tingkat perkembangan dan lingkungan serta interaksi antara faktor-faktor tersebut (Schmidt, 2000). Sebagai contoh adalah cendawan Fusarium sp. dan Aspergillus sp. yang sangat berpotensi untuk menimbulkan penyakit pada benih Paraserianthes falcataria (Zanzibar et al., 2001).

Berdasarkan hal tersebut maka penelitian ini dilakukan untuk mengetahui seberapa besar pengaruh infeksi cendawan Fusarium sp. dan Aspergillus sp. terhadap viabilitas benih, pertumbuhan tinggi dan diameter bibit Swietenia macrophylla umur 1 bulan.

\section{BAHAN DAN METODE}

\section{A. Lokasi dan Waktu Penelitian}

Penelitian dilaksanakan di laboratorium Balai Penelitian Teknologi Perbenihan Bogor. Pelaksanaan kegiatan penelitian dilakukan pada bulan Juli sampai Oktober 2006.

\section{B. Bahan dan Alat Penelitian}

Bahan penelitian yang digunakan adalah benih S. macrophylla yang diunduh dari Hutan Penelitian Ciamis pada bulan Juli tahun 2006. Hutan Penelitian tersebut terletak di Dusun Lumbung Sari, Kecamatan Pamarican, Kabupaten Ciamis. Bahan-bahan lainnya yang juga digunakan dalam penelitian ini adalah isolat cendawan Aspergillus sp. dan Fusarium sp. murni yang berasal dari Laboratorium Penyakit Tanaman, Departemen Hama dan Penyakit Tanaman, Fakultas Pertanian IPB, Bogor. Selain itu digunakan juga aquades, media PDA (Potato Dextrose Agar), alkohol, pasir, tanah dan lain-lain. Alat-alat yang digunakan adalah autoclave, alumunium foil, kapas, cawan petri, laba erlenmeyer, beker glass, lampu bunsen, ruang isolasi (laminary airflow), bak kecambah, polybag dan alat tulis menulis.

\section{Metode Penelitian}

Buah S. macrophylla dikumpulkan dari pohon induk dengan cara memanjat, lalu buah dipetik dengan menggunakan galah berkait. Buah yang dikumpulkan hanya buah S. macrophylla yang dipetik langsung dari pohon, sedangkan buah yang telah jatuh ke tanah tidak dikumpulkan. Kemudian buah diekstraksi dengan cara memecah buah dan benih dikeluarkan. Benih dibersihkan dengan memotong sayap benih pada bagian atasnya, kemudian benih disortasi dengan kriteria benih sehat dan tidak ada cacat atau rusak. Benih S. macrophylla dijemur selama 1 hari, lalu dikeringanginkan selama 4 hari untuk menurunkan kadar air hingga sebesar 7,55\% (Balai Teknologi Perbenihan, 2000). Dengan cara tersebut benih S. macrophylla segar mampu menghasilkan daya kecambah yang tertinggi (93\%) dan mengandung sedikit cendawan (Bramasto et al., 2005). Pengujian kadar air menggunakan metode oven tetap sesuai dengan standar ISTA(1999).

Filtrat cendawan Aspergillus sp. dan Fusarium sp. diperoleh dari hasil perbanyakan isolat murni cendawan Aspergillus sp. dan Fusarium sp. Perbanyakan isolat murni dari kedua cendawan tersebut 
dilakukan dengan cara menanamnya pada media PDA yang telah disiapkan di dalam cawan petri. Setelah diinkubasikan selama 15 hari, koloni cendawan yang tumbuh dipisahkan dari media PDA dengan cara menyiramkan aquades $10 \mathrm{ml}$ secara perlahan lalu dilakukan penyaringan dengan menggunakan kertas saring Whatman 41 sehingga diperoleh filtrat biakannya. Kemudian filtrat biakan dimasukkan ke dalam beberapa beker glass.

Benih S. macrophylla segar yang akan diinokulasi dengan cendawan Aspergillus sp. dan Fusarium sp. dimasukkan ke dalam beker glass yang telah berisi filtrat cendawan tersebut. Perendaman dilakukan selama 1 jam. Untuk benih yang tidak diinokulasi cendawan (kontrol), tindakan yang dilakukan hanya merendam benih dalam air steril. Setelah perendaman, benih lalu ditiriskan, kemudian ditabur dalam bak kecambah yang berisi media pasir yang telah disterilkan dengan cara digoreng selama 2 jam. Perkecambahan benih dilakukan di rumah kaca. Setiap perlakuan diulang 3 kali masing-masing terdiri dari 100 buah benih. Tolok ukur pengamatan adalah daya kecambah benih, yaitu banyaknya persentase kecambah normal pada pengamatan selama 30 hari setelah tanam, dengan persamaan sebagai berikut:

$$
\text { Daya kecambah }(\%)=\frac{\text { Jumlah kecambah normal }}{\text { Total benih yang ditabur }} \quad \mathrm{X} 100 \%
$$

Setelah kecambah berumur 3 (tiga) minggu dilakukan penyapihan ke dalam polybag. Media sapih yang digunakan adalah campuran pasir sungai dan tanah yang telah disterilkan dengan perbandingan 1:1. Penyiraman dilakukan sekali sehari, setiap pagi hari. Setelah bibit berumur 1 bulan dari saat penyapihan dilakukan pengukuran tinggi dan diameter bibit. Tinggi bibit adalah panjang bibit yang diukur mulai dari permukaan media hingga ke bagian pucuk bibit. Pengukuran diameter bibit dilakukan pada ketinggian 1 cm dari leher akar.

Rancangan penelitian yang digunakan untuk mengetahui pengaruh infeksi cendawan terhadap pertumbuhan tinggi dan diameter bibit $S$. macrophylla adalah Rancangan Acak Lengkap (RAL) dengan 3 perlakuan yaitu kontrol, cendawan Aspergillus sp. dan cendawan Fusarium sp. Setiap perlakuan yang diuji diulang sebanyak 3 kali dan masing-masing ulangan terdiri dari 10 bibit.

Data hasil pengamatan dianalisis dengan analisis keragaman. Jika hasil analisis tersebut menunjukkan perbedaan yang nyata, maka analisa dilanjutkan dengan Uji Jarak Berganda Duncan (DMRT).

\section{HASIL DAN PEMBAHASAN}

\section{A. Hasil}

Rata-rata daya kecambah benih Swietenia macrophylla setelah diinokulasi cendawan dapat dilihat dalam Gambar 1. Dari Gambar 1 terlihat bahwa daya kecambah benih S. macrophyla menurun setelah diberi perlakuan inokulasi cendawan Fusarium sp. dan Aspergillus sp. Daya kecambah benih terinfeksi cendawan Fusarium sp. dan Aspergillus sp. masing-masing sebesar 36,75\% dan 15,75\%. Sedangkan daya kecambah benih yang tidak terinfeksi (kontrol) sebesar 76,25\%.

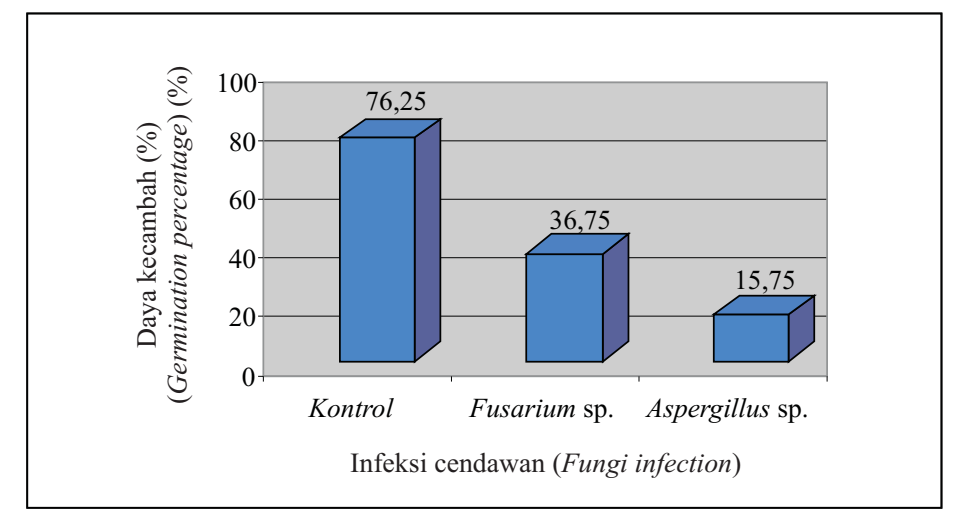

Gambar(Figure) 1. Rata-rata daya kecambah benih S. macrophylla setelah inokulasi cendawan (Average of S. macrophylla seed germination percentage after fungi inoculation) 
Berdasarkan hasil analisis keragaman (Lampiran 1) diketahui bahwa perlakuan inokulasi cendawan memberikan pengaruh yang nyata terhadap pertumbuhan tinggi dan diameter bibit $S$. macrophylla umur 1 tahun. Kemudian berdasarkan hasil uji lanjut (Tabel 1) diketahui bahwa benih yang diinokulasi cendawan Fusarium sp. dan Aspergillus sp. menghasilkan bibit dengan pertumbuhan tinggi yang lebih rendah dibandingkan dengan bibit yang berasal dari benih tidak diinokulasi dengan cendawan (kontrol). Pertumbuhan diameter terendah terlihat pada bibit yang berasal dari benih S. macrophylla yang diinokulasi cendawan Aspergillus sp.

Tabel (Table) 1. Rata-rata pertumbuhan tinggi dan diameter bibit S. macrophylla umur 1 bulan (The average growth of 1 month old S. macrophylla seedling)

\begin{tabular}{|l|c|c|}
\hline $\begin{array}{c}\text { Jenis infeksi } \\
\text { (Infection type) }\end{array}$ & $\begin{array}{c}\text { Tinggi } \\
(\text { Height })(\mathrm{cm})\end{array}$ & $\begin{array}{c}\text { Diameter } \\
\text { (Diameter })(\mathrm{mm})\end{array}$ \\
\hline Kontrol (control) & $27,48 \mathrm{a}$ & $0,10 \mathrm{a}$ \\
\hline Fusarium $\mathrm{sp}$. & $24,29 \mathrm{~b}$ & $0,09 \mathrm{a} \mathrm{b}$ \\
\hline Aspergillus $\mathrm{sp}$. & $20,38 \mathrm{c}$ & $0,08 \mathrm{~b}$ \\
\hline
\end{tabular}

Keterangan (Remarks) : Angka- angka yang diikuti dengan huruf yang sama pada kolom yang sama menunjukkan tidak berbeda nyata pada tingkat kepercayaan $95 \%$ (Values followed by the same letters in the same coluomn are not significantly different at $95 \%$ convidence level)

\section{B. Pembahasan}

Infeksi cendawan pada benih menyebabkan berkurangnya energi untuk perkecambahan dan berpengaruh terhadap perkembangan embrio selama perkecambahan (Halloin, 1986 dalam Schmidt, 2000). Kemampuan sel atau jaringan benih untuk melaksanakan fungsi-fungsi fisiologis secara normal menjadi berkurang atau berhenti, akibatnya pertumbuhan benih menjadi terganggu dan atau mati (Yunasfi, 2002). Hal inilah yang menyebabkan cendawan menurunkan viabilitas benih, bahkan jika serangan sudah sangat parah benih menjadi busuk dan tidak dapat berkecambah (Bramasto et al., 2008). Kondisi tersebut juga terjadi pada benih $S$. macrophylla yang digunakan dalam penelitian ini, dimana benih S. macrophylla yang diinokulasi cendawan Fusarium sp. dan Aspergillus sp. cenderung menghasilkan daya kecambah yang lebih kecil dibandingkan benih yang tidak diinokulasi cendawan. Hal ini menunjukkan bahwa cendawan Fusarium sp. dan Aspergillus sp. menurunkan viabilitas benih $S$. macrophylla yang dicirikan dari nilai daya kecambahnya. Kedua jenis cendawan tersebut dapat dikategorikan sebagai jenis-jenis cendawan patogen pada benih S. macrophylla karena terbukti menyebabkan penurunan kualitas mutu benih. Rahayu (1999) menyebutkan bahwa Fusarium sp. merupakan salah satu jenis cendawan lapang yang dapat mengakibatkan warna benih berubah, perkecambahan benih terhambat dan menyebabkan penyakit di persemaian atau pada tanaman dewasa.

Pada umumnya benih $S$. macrophylla segar mempunyai daya kecambah yang cukup tinggi yaitu berkisar antara 90\% - 100\% (Bramasto et al., 2005; Balai Teknologi Perbenihan, 2000). Namun dalam penelitian ini rata-rata daya kecambah benih $S$. macrophylla yang tidak diinokulasi cendawan (kontrol) relatif rendah yaitu sebesar $76,25 \%$.

Kesehatan benih dapat mempengaruhi jumlah dan kualitas bibit yang dihasilkan, sehingga berpengaruh juga terhadap tingkat produktivitas bibit di persemaian. Pada beberapa kasus, keberadaan cendawan benih pada mulanya tidak mempengaruhi daya kecambah (viabilitas) benih, namun pengaruhnya baru terlihat di pembibitan atau pada saat tanaman muda (Semangun, 2000), karena kecambah yang dapat bertahan hidup tersebut cenderung menjadi sangat rentan terhadap serangan hama atau cendawan lain yang terdapat di pembibitan. Perkembangan bibit menjadi tidak sempurna, sehingga mengakibatkan kualitas bibit menurun atau bahkan mengakibatkan kematian.

Berdasarkan hasil penelitian (Tabel 1) diketahui bahwa pertumbuhan tinggi bibit S. macrophylla yang berasal dari benih yang diinokulasi dengan cendawan Fusarium sp. dan Aspergillus sp. memperlihatkan pertumbuhan tinggi yang lebih lambat dibandingkan dengan benih yang tidak dinokulasi (kontrol). Terhambatnya pertumbuhan tinggi tersebut karena keberadaan cendawan Fusarium sp. dan 
Aspergillus sp. mengganggu pertumbuhan bagian-bagian tumbuhan. Hal yang sama juga terjadi pada bibit pinus seperti yang dilaporkan Ress dan Philips (1986) dalam Schmidt (2000), yaitu bahwa infeksi cendawan Aspergillus spp. pada akar kecambah Pinus spp. menghambat pertumbuhan bibit dan menyebabkan kematian. Booth dan Waterson (1964) dalam Baharuddin et al. (2000) menjelaskan bahwa Fusarium dapat menyerang semua tahap perkembangan tanaman bahkan dapat terbawa oleh benih dan jika jumlah inokulum cukup tinggi dan atau infeksi awal terjadi pada tahap pembibitan, maka kemungkinan besar tanaman akan mati pada tahap pembibitan. Selanjutnya Yunasfi (2002) menjelaskan bahwa proses gangguan cendawan Fusarium sp. terhadap metabolisme tanaman adalah dengan cara menghambat pergerakan air dalam tumbuh tanaman sehingga menjadi layu patogis yang tidak bisa balik dan berakibat kematian tanaman. Kerentanan bibit S. macrophylla terhadap serangan cendawan Fusarium sp. tersebut kemungkinan juga dapat disebabkan umur bibit yang masih muda (1 bulan). Zanzibar et al. (2002) menyatakan bahwa terdapat korelasi antara umur bibit dengan kemampuan menahan serangan cendawan patogen. Hal ini dibuktikannya pada bibit $A$. crassicarpa, yang mana bibit yang berumur lebih tua cenderung semakin tahan terhadap serangan cendawan patogen.

Untuk menghindari kerugian yang sangat besar akibat gangguan penyakit pada benih, maka perlu adanya upaya pencegahan sedini mungkin yaitu salah satunya dengan memperhatikan faktor fitosanitary (kesehatan) benih disamping faktor kualitas fisik, fisiologis, dan genetiknya. Penggunaan benih yang cacat, rusak atau benih-benih yang telah ada di atas tanah dalam waktu yang lama sebaiknya dihindari karena biasanya mengandung "cendawan terbawa benih". Beberapa cendawan terbawa benih walaupun tidak berpengaruh terhadap perkecambahan dan pembibitan, akan terbawa hingga tanaman dewasa yang menyebabkan penyakit bercak daun dan kanker batang pada tanaman S. macrophylla dewasa (Anggraeni dan Hardi, 2006). Bibit yang kuat dan mampu bertahan hidup juga tidak terlepas dari serangan cendawan karena kondisi lingkungan juga mempengaruhi perkembangan cendawan.

\section{KESIMPULAN}

1. Cendawan Fusarium sp. dan Aspergillus sp. menurunkan viabilitas benih S. macrophylla.

2. Infeksi cendawan Fusarium sp. dan Aspergillus sp. berpengaruh terhadap pertumbuhan tinggi dan diameter bibit $S$. macrophylla yang berumur 1 bulan.

\section{DAFTAR PUSTAKA}

Anggareni, I. dan Hardi. 2006. Hama dan Penyakit Hutan Tanaman serta Cara Pengendaliannya. Info Hutan Tanaman Vol. 1 (1) : 1 - 20. Pusat Penelitian dan Pengembangan Hutan Tanaman. Bogor.

Baharuddin, N. Amin dan Kurniati. 2004. Pengamatan Penyakit Penting pada Beberapa Fase Perkembangan Tanaman Kapas (Gossypium hirsutum 1.) Transgenik bt di Lahan Sawah dan Lahan Kering. Jurnal Sains \& Teknologi, Desember 2004, Vol. 4 (3) : 101-108. Makassar.

Balai Teknologi Perbenihan. 2000. Mahoni (Swietenia macrophylla King) dalam Atlas Benih Tanaman Hutan Indonesia Jilid I. Publikasi Khusus Vol. 2 (3) : 32- 34.

Bramasto, Y., M. Zanzibar, Widodo, Suryowiyono dan S. R. Simanjuntak. 2005. Laporan Hasil Penelitian nomor 440/12/2005. Balai Penelitian dan Pengembangan Teknologi Perbenihan. Tidak diterbitkan.

Bramasto, Y., M. Zanzibar dan T. Suharti. 2008. Teknik Pengelolaan Hama dan Penyakit pada Benih Tanaman Hutan Rakyat. Info Benih Vol. 12 (2) : 117 - 126. Pusat Penelitian dan Pengembangan Hutan Tanaman. Bogor.

ISTA. 1999. International Rules for Seed Testing. Proc. Int. Seed Testing Association Volume 31 (1). Wageningen.

Neegaard, P. 1979. Seed Pathology Volume 1. The Macmillan Press Ltd. London. 
Rahayu, S. 1999. Penyakit Tanaman Hutan di Indonesia (Gejala, penyebab dan teknik pengendaliannya). Penerbit Kanisius. Yogjakarta.

Schmidt, L. 2000. Pedoman Penanganan Benih Tanaman Hutan Tropis dan Sub Tropis. Direktorat Jenderal Rehabilitasi Lahan dan Perhutanan Sosial, Dephut Bekerjasama dengan Indonesia Forest Seed Project (IFSP). Jakarta.

Semangun, H. 2000. Penyakit-penyakit Tanaman Holtikultura di Indonesia. Gadjah Mada University Press.

Yunasfi. 2002. Faktor-faktor yang Mempengaruhi Perkembangan Penyakit dan Penyakit yang Disebabkan oleh Cendawan. Fakultas Pertanian Jurusan Ilmu Kehutanan Sumatera Utara. http://library.usu.ac.id/download/fp/hutan-edi\%20batara14.pdf. Diakses pada tanggal 19 Agustus 2008.

Zanzibar, M., D. J. Sudradjat, dan H. Pribadi. 2001. Pengaruh Perlakuan Gas $\mathrm{CO}_{2}$, Fungisida dan bakterisida pada penyimpanan Benih Paraserianthes falcataria (L) Nielsen. Buletin Teknologi Perbenihan Vol 8 (1) : 1 - 11. Pusat Penelitian dan Pengembangan Hutan dan Konservasi Alam. Balai Teknologi Perbenihan. Bogor.

Zanzibar, M., Achmad dan N. Herdiana. 2002. Pengaruh Penambahan Pasir pada Tanah Podsolik Merah Kuning terhadap Intensitas Serangan Patogen Lodoh (Rhizoctonia solani) pada Beberapa Tingkat Umur Semai Acacia crassicarpa. Buletin Teknologi Perbenihan Vol 9(1): 27 29. Pusat Penelitian dan Pengembangan Bioteknologi dan Pemuliaan Tanaman Hutan. Balai Penelitian dan Pengembangan Teknologi Perbenihan. Bogor. 
Lampiran(Appendix) 1. Analisis keragaman pengaruh infeksi cendawan terhadap pertumbuhan tinggi dan diameter bibit Swietenia macrophylla umur 1 bulan (Analysis of variance as to the effect of fungi infection on growth of height and diameter of Swietenia macrophylla seedling)

\begin{tabular}{|c|c|c|c|c|c|}
\hline $\begin{array}{c}\text { Parameter } \\
\text { (Parameters) }\end{array}$ & $\begin{array}{c}\text { Sumber keragaman } \\
\text { (Source of } \\
\text { variation) }\end{array}$ & $\begin{array}{l}\text { Derajat } \\
\text { bebas } \\
\text { (Degrees of } \\
\text { freedom) }\end{array}$ & $\begin{array}{c}\text { Jumlah } \\
\text { Kuadrat } \\
\text { (Number of } \\
\text { square) }\end{array}$ & $\begin{array}{c}\text { Kuadrat } \\
\text { tengah (Mean } \\
\text { of square) }\end{array}$ & $\begin{array}{l}\mathrm{F}_{\text {hitung }} \\
\left(F_{\text {value }}\right)\end{array}$ \\
\hline $\begin{array}{l}\text { Pertumbuhan } \\
\text { tinggi (height } \\
\text { growth) }\end{array}$ & $\begin{array}{l}\text { Perlakuan } \\
\text { (treatment) } \\
\text { Sisa (residual) } \\
\text { Total (total) }\end{array}$ & $\begin{array}{r}2 \\
117 \\
119\end{array}$ & $\begin{array}{l}1011,753 \\
1858,087 \\
2869,840\end{array}$ & $\begin{array}{r}505,876 \\
15,881\end{array}$ & $31,85 * *$ \\
\hline $\begin{array}{l}\text { Pertumbuhan } \\
\text { diameter } \\
\text { (diameter } \\
\text { growth) }\end{array}$ & $\begin{array}{l}\text { Perlakuan } \\
\text { (treatment) } \\
\text { Sisa (residual) } \\
\text { Total (total) }\end{array}$ & $\begin{array}{r}2 \\
117 \\
119\end{array}$ & $\begin{array}{l}0,007 \\
0,097 \\
0,103\end{array}$ & $\begin{array}{l}0,003 \\
0,001\end{array}$ & $3,96 *$ \\
\hline
\end{tabular}

Keterangan (Remarks) : ** = Berbeda sangat nyata pada selang kepercayaan 99\% (Highly significantly different at $99 \%$ confidence level) * = Berbeda nyata pada selang kepercayaan 95\% (Significantly different at $95 \%$ confidence level) 